\title{
Contrasting Pressure - Temperature Evolution of Pelitic Schists, Gneisses and Eclogites in Kaghan-Naran Valley, Pakistan Himalaya
}

\author{
Hafiz U Rehman $§ *$, Hiroshi Yamamoto†, Yoshiyuki Kanekoł and AB Kausar§ \\ †Department of Earth and Environmental Sciences, Kagoshima University, Kagoshima 890-0065, JAPAN \\ ‡Graduate School of Environment and Information Sciences, Yokohama National University, Yokohama 240-8501, JAPAN \\ §Geoscience Laboratory, Geological Survey of Pakistan, Shahzad Town, Islamabad, PAKISTAN
}

*To whom correspondenceshould be addressed. E-mail: gsehafez@moon.sci.kagoshima-u.ac.jp

A classical example of Barrovian type metamorphic sequenceis observed in pelitic schists, gneisses and eclogites from Balakot in the southwest to Babusar Passin thenortheast, Kaghan - Naran Valley, Pakistan Himalaya. This sequence comprises the first appearance of chlorite followed by biotite, garnet, staurolite, kyanite and sillimanite. Based on mineral chemistry, pressuretemperature conditions of garnet, staurolite, kyanite zones and eclogites in kyanitezone wereestimated as $6.2-6.9 \mathrm{kbar}$ and 420 - $478^{\circ} \mathrm{C} ; 7.1-8.3 \mathrm{~kb}$ ar and $558-605^{\circ} \mathrm{C} ; 12.8-14.6 \mathrm{kbar}$ and 658 $700^{\circ} \mathrm{C}$; and $27-32 \mathrm{kbar}$ and $727-799^{\circ} \mathrm{C}$ respectively (Figure1).

Based on detailed field survey in the study area and petrography, the previously called basement and cover sequence of Higher Himalayan sequencefrom thestructural bottom to top is recently classified into three tectonic units referred herein as unitI, II and III (thisstudy). Unit I mainly comprisesthebasement sequenceand has a tectonic contact with the Main Central Thrust to the southwest. This unit mainly consists of pelitic schists and gneisses. Unit II representing ultrahigh-pressure (UHP) metamorphism, is sandwiched in between units I and III. It constitutes thelower cover having pelitic schists; gneisses; felsic gneisses, calcareous gneisses/marbles and eclogites, while unit III is uppermost part of the cover sequence and has a tectonic juxtaposition with low gradeTethyan metasediments locally and Main Mantle Thrust in particular to the northeast. It is also comprised of low grade pelitic gneisses.
Presence of coesite relics in clinopyroxene from eclogites and as inclusions in zircon in gneisses from Higher Himalayan crystalline rocks (unit II) gives evidence of deep continental subduction. Geothermal interpolationsfrom petrological dataand presence of coesite proves the hypothesis that deep continental subduction occurred when Indian platecollided with Asian plate sandwiching Kohistan Arcapproximatelyat53Ma with theclosure ofTethys. Atthecollision boundarymarked by Main MantleThrust, continental rocks along with oceanic crust subducted beneath Kohistan Arc reaching about $100 \pm 10 \mathrm{~km}$ depth.

Tectonic setup and relative $\mathrm{P}$ - T conditions (Figure $\mathbf{2 a}, \mathbf{b}$ ) interprets that the grade of metamorphism in Higher Himalayan sequenceincreased towardsnorth closeto thesubduction front. Ultrahigh-pressure metamorphism took place in unit II when it reached to a considerable depth sufficient for the development of coesite. At this event the felsic/ pelitic rocks metamorphosed to UHP gneisses and basaltic sills and flows metamorphosed to eclogites. TheUHP rocksunderwentmedium-pressureBarrovian metamorphism during their exhumation stage. SHRIMP data for zircon core and rims from the felsic gneisses of unit II close to eclogite body yields the protolith age as of 253-170 Ma and UHP metamorphic ageas 46.2 $\pm 0.7 \mathrm{Ma}$ (Kaneko et al. 2003). Petrologic and $\mathrm{P}-\mathrm{T}$ dataindicatethat these rocks exhumed to earth surface from depths of up to about 90 110 km evidenced by coesite retrogression to quartzand omphaciteto amphibolein eclogites.

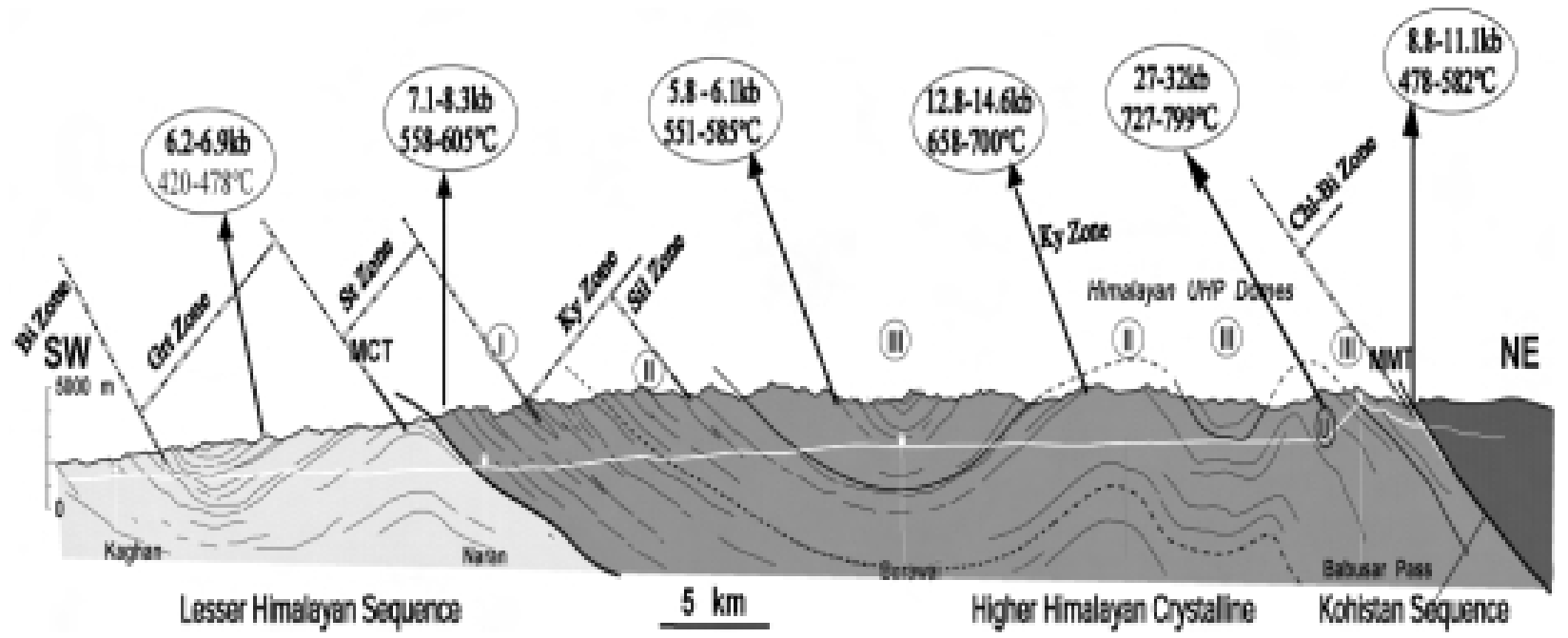

FIGURE 1. Cross section map of Kaghan - Naran Valley showing Thermobaric structure with P - T data for Grt, St, Ky zone of Unit I, II and III. (U) shows UHP rocks locality. 
a

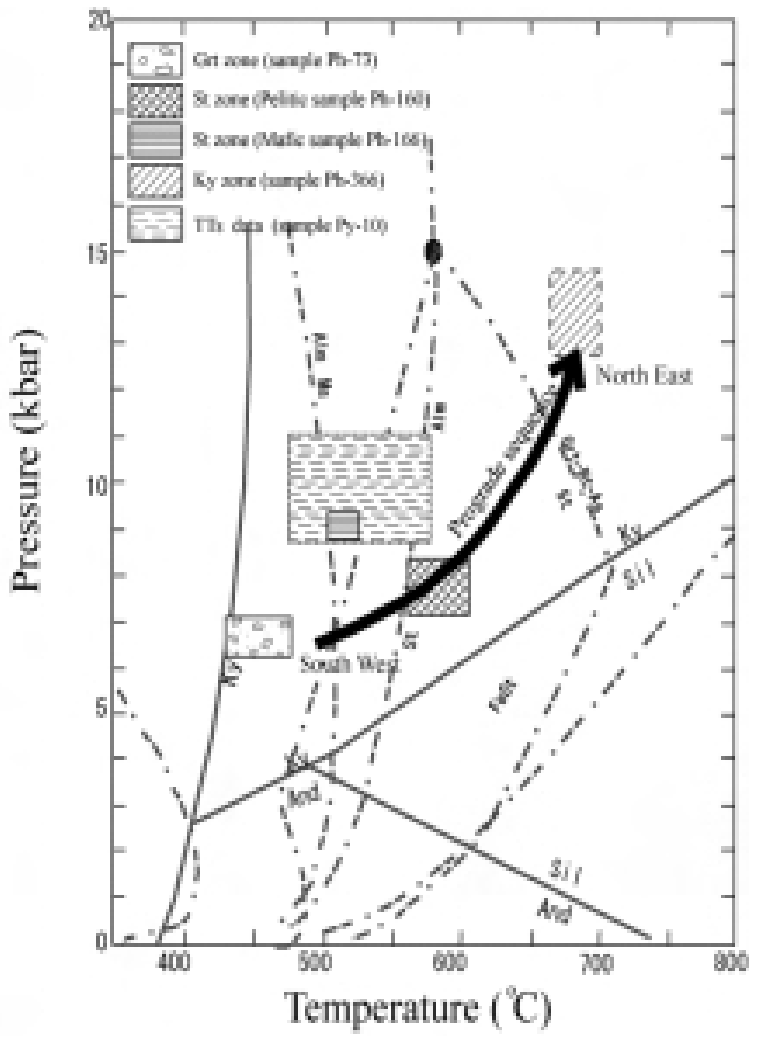

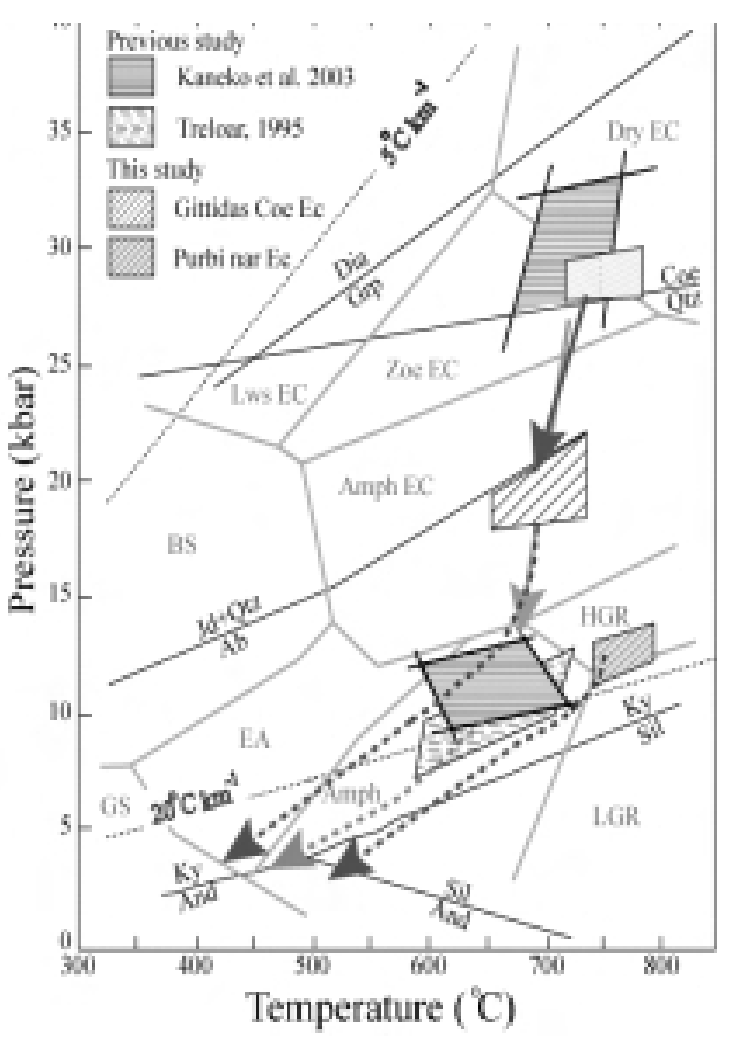

FIGURE 2. (a) Pressure-Temperature plot from gr, st, st-ky zones of pelitic rocks and from Tethyan metasediments in the Kaghan valley. P-T conditions are obtained from Thermocalc software (Powell and Holland 1988). P-T grids for petrogenic phases, stability fields for biotite, garnet, staurolite and aluminosilicates, and reaction curves are adopted from KFASH System of Spear and Cheney (1989). (b) Pressure-Temperature plot of the Kaghan UHP rocks calculated from the average P-T conditions of Thermocalc software after Powell and Holland (1994). The P-T conditions of Kaghan gneiss (Treloar 1995) and (Kaneko et al. 2003) are shown for comparison.

\section{References}

Kaneko Y, I Katayama, H Yamamoto, K Misawa, M Ishikawa, HU Rehman AB Kausar and K Shiraishi. 2003. Timing of Himalayan ultrahighpressure metamorphism: sinking rate and subduction angle of the Indian continental crust beneath Asia. J Metam Geol 21(6): p 589-99

Powell R and TJB Holland. 1988. An internally consistent dataset with uncertainties and correlations. III. Application methods, worked examples and computer program. J Metam Geol I6: 173-204
Powell R and TJB Holland. 1994. Optimal geothermometry and geobarometry. Amer Miner 79: 120-133

Spear FS and JT Cheney. 1989. A petrogenitic grid for pelitic schists in the system SiO2-Al2O3-FeO-MgO-K2O-H2O. Contrib Miner Petrol 101: 149-164

Treloar PJ. 1995. Pressure-temperature-time paths and the relationship between collision, deformation and metamorphism in thenorth-west Himalaya. Geol Jour 30: 333-348 